\title{
The Effect of Science Process Skills on Study Critical Thinking Ability in Scientific Learning
}

\author{
Haerul Pathoni ${ }^{1}$, Wawan Kurniawan ${ }^{1}$, Louisiana Muliawati ${ }^{2}$, Dwi Agus Kurniawan ${ }^{1, *}$, \\ Retno Wulan Dari ${ }^{1}$, Aziza Putri Ningsi ${ }^{1}$, Dinda Desma Romadona ${ }^{1}$ \\ ${ }^{1}$ Department of Physics Education, Faculty of Teaching and Education, Universitas Jambi, Indonesia \\ ${ }^{2}$ Faculty of Tadris and Tarbiyah, Uin Sulthan Thaha Saifuddin Jambi, Indonesia
}

Received July 26, 2020; Revised August 22, 2020; Accepted September 29, 2020

\begin{abstract}
Cite This Paper in the following Citation Styles
(a): [1] Haerul Pathoni, Wawan Kurniawan, Louisiana Muliawati, Dwi Agus Kurniawan, Retno Wulan Dari, Aziza Putri Ningsi, Dinda Desma Romadona, "The Effect of Science Process Skills on Study Critical Thinking Ability in Scientific Learning," Universal Journal of Educational Research, Vol. 8, No. 11, pp. 5648 - 5659, 2020. DOI: 10.13189/ujer.2020.081169.
\end{abstract}

(b): Haerul Pathoni, Wawan Kurniawan, Louisiana Muliawati, Dwi Agus Kurniawan, Retno Wulan Dari, Aziza Putri Ningsi, Dinda Desma Romadona (2020). The Effect of Science Process Skills on Study Critical Thinking Ability in Scientific Learning. Universal Journal of Educational Research, 8(11), 5648 - 5659. DOI: 10.13189/ujer.2020.081169.

Copyright $\bigcirc 2020$ by authors, all rights reserved. Authors agree that this article remains permanently open access under the terms of the Creative Commons Attribution License 4.0 International License

\begin{abstract}
This study aims to see the effect of science process skills on the critical thinking abilities of Junior High School and Islamic Junior High School Jambi City students on the density and reflection of the material in the mirror. The research method used was mixed methods, while the design used was sequential explanatory. The research was conducted at SMP Adhyaksa 1 Jambi City and MTS Al-Jauharen Jambi City. The sampling technique used in this study was cluster sampling. Instrument collecting data in this study used observation sheets science process skills, critical thinking skills test questions, and interview sheets. Data were analyzed using descriptive statistics and inferential statistics. Based on the results of a simple linear regression test, it was obtained $t$ count $>t$ table, namely $6.492>2.0032$ and $2.320>2.0032$, it can be said that there is a significant influence between science process skills and critical thinking skills in density material and its reflection on the mirror. This study shows that students of SMP and MTs have low science process skills and critical thinking skills. To improve sains process skills and critical thinking skills needed to do the learning that is centered on students and familiarize students doing the learning level of the high and the need for understanding of concepts through practical activities.
\end{abstract}

Keywords Science Process Skills, Critical Thinking Skills, Science, Physics

\section{Introduction}

Education is a process of improving the quality of life and acquiring and instilling skills that students carry out. This requires knowledge to be continuously developed per time [1]. Education is the most potent weapon that can be used to change the world [2]. Training can improve the quality of each individual [3]. The aim of education in Indonesia is to increase resources that are faithful, pious, ethical, disciplined, responsible, and have high intellectual intelligence. In education in Indonesia itself, there are several levels, one of which is the Senior High School level [4]. Senior High School is a level of education that students must take before continuing to higher education. In high school education, studying various sciences, one of which is studying physics.

Physics is a branch of natural science that discusses the symptoms and properties of objects that exist in nature physically and formulated mathematically [5] [6]. Stated that physics is an experimental science developed by physicists through experiments to prove the theory and to improve and refine it[7]. As reported by [8], " theoretical physicists use the results of operations to refine Reviews their ideas and at the same time suggest new investigations. " From several previous quotes, it can be concluded that 
physics is an experimental science aiming to prove the truth and improve it. Therefore, to determine the reality of a theory, it needs to be supported by practicum activities. Practical activities will form science process skills and critical thinking skills in students. Science process skills are skills that need to be instilled in practice and are owned by students [9]. Science process skills are thinking skills used to create knowledge, solve problems, and formulate results [10]. Students' science process skills can be seen from practicum activities that lead to concepts in learning and the application of science [11].

The skills that must be developed by students are science process skills. Science process skills (SPS) are needed and possessed by students to face competition between humans in the era of globalization [12]. Science process skills are students' abilities to apply scientific methods in understanding, developing \& discovering science[13]. Through science process skills, bias encourages students to learn facts and concepts of knowledge and develop the required attitudes and values.

Science process skills are needed to acquire, develop, and apply concepts, principles, laws, and scientific theories in the form of mental, physical, and social skills [14]. Science process skills help students learn through knowledge to solve problems and find solutions [15]. Science process skills have two categories, necessary science process skills and science process integration skills [16]. Process skills consist of required qualifications, where these essential skills will be the basis for further skill development [17]. Necessary science process skills include observing, classifying, predicting, measuring, concluding, and communicating [18]. Integrated science process skills can be mastered after mastering the necessary process skills. Integration science process skills include: identifying variables, making data tables, making graphs, describing relationships between variables, collecting and organizing data, analyzing experiments, forming hypotheses, defining variable operationally, designing experiments, conducting experiments [19]. So that science process skills can support students in developing critical thinking skills.

Critical thinking is a part of high-order thinking (high order thinking skills) [20]. Critical thinking is a crucial competency that must be possessed to solve the problems needed for individuals to live successfully and live responsibly and for society to face present and future challenges. [21]. The critical thinking process enables individuals to make reasonable judgments both in the classroom and everyday life [22]. Critical thinking defines students who are "able to think" logically and deeply, search for data, and systematically evaluate data as a result of the learning process. [23]. Critical thinking also trains students to think logically and not accept things easily.

According to Ennis, there are five indicators of critical thinking skills. Each sign consists of sub-indicators that have linkages meaning of each other (1985). The description of the indicators and sub-indicators of critical thinking skills are as follows:

- Basic clarification (elementary clarification), including focusing questions; analyzing arguments; asking questions and answering clarifying questions or challenges.

- The basis for making decisions or support (the basis for the resolution / necessary support), including considering the credibility of the source; making observations and assessing observation reports.

- Inference (inference), including deduction and evaluating deduction; induction and assessing induction; creating and evaluating value statements.

- Clarifying further (advanced clarification), includes: defining the term and rating the definition; identifying assumptions.

- Strategies and tactics (strategies and tactics), including determining actions; interacting with other people.

Critical thinking aims to expand the views (horizons) of students as support for their ideals. Critical thinkers can seek, understand, and evaluate relevant statements logically and rationally during problem-solving or decision making [24]. The application of critical thinking skills in learning is vital, this is in line with the opinion [25], the ability to think critically is a learning method or a right way that we must instill in the physics learning process.

Excellent critical thinking skills are essential for students to analyze thoughts and arguments and solve problems carefully [26]. To have excellent critical thinking skills, students must have critical thinking skills in general and unique aspects. The ability to think critically in individual elements, namely students can understand the concepts being studied. In contrast, students' general elements can solve problems and phenomena in everyday life that require understanding the correct concepts of physics [27]. The low ability of students to think critically can be caused by students who do not master the concepts and learning materials [28]. Misunderstanding of the concept of learning can lead to low student learning outcomes [29]. Therefore, it is important to know students' critical thinking skills in any physics learning material. Based on the explanation above, critical thinking can develop science process skills in students.

Based on the description above, the researcher will analyze the effect of science process skills on students' critical thinking skills in learning physics material density and reflection on mirrors at SMP Adhyaksa 1 Jambi City and MTS Aljauharen Jambi City. This study aimed to see the effect of science process skills on the critical thinking skills of Jambi City Senior High School students on density and reflection on mirrors.

\section{Materials and Methods}

The research method used is mixed methods (mixed 
methods), while the design used is sequential explanatory, which combines quantitative and qualitative research sequentially first using quantitative methods then qualitative methods. [30]. The use of sequential illustrative design starts from collecting and analyzing quantitative data followed by collecting and analyzing qualitative data [31]. In this method, quantitative data is preferred. Quantitative research emphasizes numerical assessment and is descriptive [32]. Qualitative methods serve to prove, deepen, and expand the quantitative data.

In this study, data collection techniques used science process skills observation sheets, critical thinking skills test questions, and interview sheets. The method of collecting quantitative data uses the science process skills observation sheet using 16 indicators with 46 statements and the critical thinking skills test questions using five symbols with ten questions. Interviews were conducted with two students per class and to 2 teachers who taught physics material.

The sample used by the researcher was 58 students of class IX Junior High School Adhyaksa 1 Jambi City and IX grade students of Islamic Junior High School Aljauharen Jambi City. The sampling technique in this study using cluster sampling. Cluster sampling (Area Sampling) is used to determine the sample if the object to be studied or the data source is huge, for example, the population of a country, province, or district [30].

The instrument used in this study was the science process skills observation sheet, the critical thinking ability test questions that had been validated by expert validators. The things observed in this study were the process skills that students had when doing practical activities in the laboratory and the ability to think critically after doing practicum activities. Ten observers assisted this observation. The percentage for each indicator sought is then stated in several categories, namely the naughty, wrong, good, perfect class.
Data analysis was carried out on quantitative data and qualitative data. This quantitative data analysis technique uses statistical analysis; namely, descriptive statistical analysis and inferential statistical analysis, carried out using the SPSS application. The descriptive statistical analysis describes data from the average, maximum, and minimum values to quickly obtain an overview of the characteristics of the object from the data. Meanwhile, inferential analysis is used to test hypotheses with the following steps: 1) doing prerequisite tests first in the form of normality test and linearity test; 2) conducting a hypothesis test in the type of a Simple Linear Regression test; and 3) comparing $t$ table with $t$ count to conclude whether $\mathrm{Ho}$ and $\mathrm{Ha}$ are accepted or rejected. Interviews were conducted to obtain qualitative data to strengthen quantitative data.

\section{Results and Analysis}

Based on the data obtained, the results of observations of mastery of students' science process skills in the material density and reflectance practicum in the mirror are shown in Table 1.

Table 1, which comes from 58 respondents from junior high school students on density material, shows that students' science process skills are categorized as not good. The science process skills of students who were categorized as very bad were in the highest percentage of 24 people with a percentage of $41.4 \%$. While the results of the descriptive analysis of the science process skills of junior high school students on the reflective material on the mirror can be seen that the students' science process skills were categorized as not good as many as 23 students with a percentage of $39.7 \%$.

Table 1. Mastery of students' science process skills on density and reflection on the mirror

\begin{tabular}{|c|c|c|c|c|c|c|c|c|}
\hline Theory & Range & Category & Mean & Median & Min & $\operatorname{Max}$ & $\%$ & f \\
\hline \multirow{4}{*}{ Density } & $46.00-80.50$ & VNG & \multirow{4}{*}{105.4} & \multirow{4}{*}{87.5} & \multirow{4}{*}{66} & \multirow{4}{*}{178} & 41.4 & 24 \\
\hline & $80.51-115.00$ & NG & & & & & 19 & 11 \\
\hline & $115.01-149.50$ & G & & & & & 20.7 & 12 \\
\hline & $149.51-184.00$ & VG & & & & & 19 & 11 \\
\hline \multirow{4}{*}{ Mirror Reflection } & $46.00-80.50$ & VNG & \multirow{4}{*}{138.0} & \multirow{4}{*}{136.5} & \multirow{4}{*}{99} & \multirow{4}{*}{175} & 27.6 & 16 \\
\hline & $80.51-115.00$ & NG & & & & & 39.7 & 23 \\
\hline & $115.01-149.50$ & G & & & & & 12.1 & 7 \\
\hline & $149.51-184.00$ & NG & & & & & 20.7 & 12 \\
\hline
\end{tabular}


Table 2. Students' mastery of science process skills on density and reflection on the mirror of each indicator

\begin{tabular}{|c|c|c|c|c|c|c|}
\hline \multirow{2}{*}{\multicolumn{2}{|c|}{ Science Process Skills }} & \multirow{2}{*}{ Indicator } & \multicolumn{4}{|c|}{ Category } \\
\hline & & & VNG (\%) & NG (\%) & G (\%) & VG $(\%)$ \\
\hline \multirow{16}{*}{ 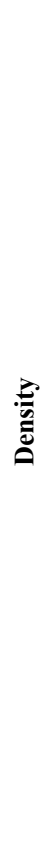 } & \multirow{6}{*}{ Basic } & Observation & 1.7 & 62.1 & 29.3 & 6.9 \\
\hline & & Classification & 12.1 & 41.4 & 19.0 & 27.6 \\
\hline & & Measure & 3.4 & 41.4 & 37.9 & 17.2 \\
\hline & & Prediction & 5.2 & 27.6 & 44.8 & 20.7 \\
\hline & & Communication & 8.6 & 41.4 & 22.4 & 27.6 \\
\hline & & Conclude & 8.6 & 34.5 & 27.6 & 29.3 \\
\hline & \multirow{10}{*}{ Integrated } & Variable identification & 37.9 & 22.4 & 17.2 & 22.4 \\
\hline & & Arrange Table data & 10.3 & 37.9 & 15.5 & 36.2 \\
\hline & & Make a chart & 29.3 & 31.0 & 22.4 & 17.2 \\
\hline & & Acquire and process data & 1.7 & 56.9 & 10.3 & 31.0 \\
\hline & & $\begin{array}{l}\text { Describe the relationship } \\
\text { between variables }\end{array}$ & 5.2 & 56.9 & 25.9 & 12.1 \\
\hline & & $\begin{array}{c}\text { Operational defines the } \\
\text { variable }\end{array}$ & 3.4 & 50.0 & 15.5 & 31.0 \\
\hline & & Make a hypothesis & 10.3 & 31.0 & 20.7 & 37.9 \\
\hline & & Experimental analysis & 0 & 74.1 & 8.6 & 17.2 \\
\hline & & Designing Investigation & 8.6 & 62.1 & 17.2 & 12.1 \\
\hline & & Conduct experiments & 8.6 & 60.3 & 8.6 & 22.4 \\
\hline \multirow{16}{*}{ 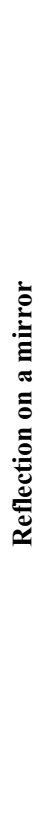 } & \multirow{6}{*}{ Basic } & Observation & 3,4 & 53,4 & 22,4 & 20,7 \\
\hline & & Classification & 3,4 & 37,9 & 31,0 & 27,6 \\
\hline & & Measure & 3,4 & 53,4 & 20,7 & 22,4 \\
\hline & & Prediction & 3,4 & 22,4 & 37,9 & 36,2 \\
\hline & & Communication & 10,3 & 50,0 & 19,0 & 20,7 \\
\hline & & Conclude & 3,4 & 58,6 & 22,4 & 15,5 \\
\hline & \multirow{10}{*}{ Integrated } & Variable Identification & 5,2 & 55,2 & 15,5 & 24,1 \\
\hline & & Construct a data table & 5,2 & 56,9 & 0,0 & 37,9 \\
\hline & & Make a chart & 10,3 & 39,7 & 36,2 & 13,8 \\
\hline & & Acquire and process data & 8,6 & 55,2 & 19,0 & 17,2 \\
\hline & & $\begin{array}{l}\text { Describe the relationship } \\
\text { between variables }\end{array}$ & 1,7 & 51,7 & 13,8 & 32,8 \\
\hline & & Identify variables operationally & 3,4 & 53,4 & 17,2 & 25,9 \\
\hline & & Make a hypothesis & 6,9 & 22,4 & 44,8 & 25,9 \\
\hline & & Experimental analysis & 5,2 & 62,1 & 25,9 & 6,9 \\
\hline & & Design investigations & 5,2 & 34,5 & 31,0 & 29,3 \\
\hline & & Conduct experiments & 5,2 & 41,4 & 29,3 & 24,1 \\
\hline
\end{tabular}

Table 2 Shows students' mastery of science process skills in necessary and integrated science process skills for each indicator, indicators of science process skills including observation, classification, measuring, prediction, communication, concluding, identifying variables, compiling data tables, making graphs, obtaining and processing data, describing the relationship between variables, identifying variables operationally, creating hypotheses, analyzing experiments, designing investigations, conducting experiments.

Based on the data obtained, the results of observations of mastery of students' critical thinking skills in the density and reflectance practicum on the mirror are shown in Table 3. 
Table 3. Mastery of Students' Critical Thinking Ability material density and reflection on the mirror

\begin{tabular}{|c|c|c|c|c|c|c|c|c|}
\hline Theory & Interval & Category & Mean & Median & Min & Max & $\%$ & f \\
\hline \multirow{4}{*}{ Density } & $10.00-17.50$ & VNG & \multirow{4}{*}{22.25} & \multirow{4}{*}{22} & \multirow{4}{*}{10} & \multirow{4}{*}{40} & 36.2 & 21 \\
\hline & $17.51-25.00$ & NG & & & & & 22.4 & 13 \\
\hline & $25.01-32.50$ & G & & & & & 24.1 & 14 \\
\hline & $32.51-40.00$ & VG & & & & & 17.2 & 10 \\
\hline \multirow{4}{*}{$\begin{array}{l}\text { Reflection } \\
\text { on a mirror }\end{array}$} & $10.00-17.50$ & VNG & \multirow{4}{*}{26.7} & \multirow{4}{*}{28.0} & \multirow{4}{*}{10} & \multirow{4}{*}{40} & 13.6 & 8 \\
\hline & $17.51-25.00$ & NG & & & & & 44.1 & 26 \\
\hline & $25.01-32.50$ & G & & & & & 22.0 & 13 \\
\hline & $32.51-40.00$ & VG & & & & & 20.3 & 12 \\
\hline
\end{tabular}

Table 3, which comes from 58 respondents from junior high school students, shows that the material because the students' critical thinking ability is categorized as very low. The critical thinking skills of students who were classified as very low were in the highest percentage of 21 people, with a rate of $36.2 \%$. While the reflection in the mirror material's ability to think critically of students categorized as low is the percentages the highest total, there are 26 students with a rate of $44.1 \%$.

Based on the data obtained, the results of the standard and linear test of students' science process skills and critical thinking skills in the material density and reflectance practicum in the mirror are shown in Table 3.

Table 4. Results of Normal and Linear Tests in Science Process Skills and Critical Thinking Skills

\begin{tabular}{ccc}
\hline Theory & $\begin{array}{c}\text { Kolmogorov-Smirnov } \\
\text { Sig. }\end{array}$ & $\begin{array}{c}\text { Deviation from } \\
\text { Linearity } \\
\text { Sig. }\end{array}$ \\
\hline Density & 0.274 & 0.268 \\
\hline $\begin{array}{c}\text { Mirror } \\
\text { Reflection }\end{array}$ & 0.507 & 0.692 \\
\hline
\end{tabular}

Data were analyzed to know the influence between two variables, namely, the influence between science process skills and students' critical thinking skills using simple linear regression tests. Still, before doing that, the normality and linearity tests were done first. According to [59], the normality test is used to determine whether the sample is from a normal distribution population or not. There are several techniques used to test the normality of data, namely the Kolmogorov-Smirnov test. The linearity test is used to assess whether the specifications of the model used are correct or not [60]. Based on the normality test results on the material density obtained significance value of $0.274>0.05$, it can be concluded that the residual value is normally distributed. Based on the linearity test results, the significance value of deviation from linearity is known to be $0.268>0.05$, so it can be concluded that there is a linear relationship between science process skills and critical thinking abilities. While the normality test results on the reflecting material on the mirror obtained significance value $0.507>0.05$, it can be concluded that the residual value is normally distributed. Based on the results of the linearity test, the significance value of deviation from linearity is known to be $0.692>0.05$, so it can be concluded that there is a linear relationship between science process skills and critical thinking abilities. From the results of the normality and linearity test, it is known that the density and reflectance material in the mirror data is homogeneous and linear, so the Pearson correlation test will be performed to see the relationship between science process skills and critical thinking abilities.

The analysis used to test the hypotheses in the study is the analysis/t-test, with the test criteria: Ho is accepted if $-\mathrm{t}$ table $\leq \mathrm{t}$ arithmetic $\geq \mathrm{t}$ table is rejected if $-\mathrm{t}$ arithmetic $<-\mathrm{t}$ table or $t$ arithmetic $>t$ table.t table is sought at $\alpha=5 \%: 2=$ $2.5 \%$ (2-tailed test) with degrees of freedom (df) n- 1 or $58-1-1=56(\mathrm{n}$ is the number of cases / samples and $\mathrm{k}$ is the number independent variable). With $\mathrm{df}=56$, the results obtained for $\mathrm{t}$ table amounted to 2.0032. While $\mathrm{t}$ arithmetic obtained from the results of simple linear regression analysis.

Based on the data obtained, the results of the regression analysis of students' science process skills and critical thinking skills in the material density and reflectance practicum in the mirror are shown in Table 5. 
Table 5. Results of regression analysis of science process skills and critical thinking skills

\begin{tabular}{ccccccc}
\hline \multirow{2}{*}{ Theory } & \multicolumn{2}{c}{ Unstandardized Coefficients } & Standardized Coefficients & \multirow{2}{*}{ t } & Sig. \\
\cline { 2 - 5 } & B & Std. Error & Beta & & 2.288 & 0.026 \\
Density & 7.170 & 3.133 & 0.655 & 6.492 & 0.000 \\
& 0.231 & .036 & & 3.832 & 0.000 \\
\multirow{2}{*}{ Mirror Reflection } & 10.417 & 2.719 & 0.296 & 2.320 & 0.024 \\
\hline
\end{tabular}

Based on table 5, the single linear regression analysis results on the material density can be seen that the $t$ value is 6.492. This value is much higher than $t$ table, which is only 2.035. Because $t$ arithmetic is more excellent than $t$-table $(6,492>2.0032)$, Ho is rejected. That is, there is a significant influence on science process skills on students' critical thinking abilities. While in the reflective material on the mirror it can be seen that the $t$ value is 2,320 . This value is much greater than $t$ table which is only 2.035 . Because $\mathrm{t}$ arithmetic is greater than the $\mathrm{t}$ table $(2,320>$ 2.0032), Ho is rejected. That is, there is a significant influence on science process skills on students' critical thinking abilities. From the results of this analysis, it can be seen that there is a significant influence between the process of science and the ability to think critically on the material density and reflection on the mirror.

Science process skills are one of the critical process skills for students to have [34]. Students can use science process skills to solve physics problems in everyday life [35]. The description of the science process skills of junior high school students on density material and reflection on the mirror is presented in table 1 . The table shows that junior high school students' science process skills on density material are low because the highest percentage of $41.4 \%$ is in the very bad category. Meanwhile, the material on the reflection of the mirror is classified as bad because the highest percentage of $39.7 \%$ is in a bad category. So the students' science process skills on the density and reflection on the mirror were classified as low.

\section{A. Observation skills}

In observation skills, indicator material density and representation in the mirror showed that it is ranked in the category of not bai $\mathrm{k}$ the third consecutive manner percentage of $62.1 \%$ on the material density and $53.4 \%$ in the reflection in the mirror material. In the indicator of observing the material density can be seen when students find the scale on the spring balance to determine the value of a line on the level, follow the object to be used or have its density measured so that they know how to hook it to the spring balance, observe the immersion so that they know how to hook it to the object, careful in finding the ruler determines the volume of the object in the density experiment, conscientious in observing the spring balance to determine the mass of the object in the density experiment in air.
As for the reflective material on the mirror on the indicators of making observations, it can be seen when students observe and feel the tools and materials to be tried out in the reflection on the concave mirror practicum, watching where the object's image is, seeing the image of the object on the screen, observing the properties of the image of the object that is formed, observing the image distance, observing the object distance, observing the focal point distance, observing the data in the table to graph the variable relationship in the reflection experiment on the concave mirror. Thus, when making observations, students do not take it seriously because they do not understand the concepts they receive. This lack of understanding is because students are only taught existing ideas without any practical proof. Because educators focus on achieving the material being taught without paying attention to student understanding.

\section{B. Classification Skills}

The indicators of the skill of classifying the density material and the reflection on the mirror show that the students are in the wrong category with a percentage of $41.4 \%$ in density material and $37.9 \%$ in the content reflected in the mirror, respectively. In the indicator of classifying material density, it can be seen when students organize the characteristics of the experimental data on the frequency of objects (seen in making tables), type the features of the empirical evidence on the density of materials in the air (seen in making table columns). The content reflecting on the mirror on the indicators of classification can be viewed when students classify the characteristics of the experimental data (seen in making tables). Thus, in this study, students were not skilled at grouping experimental data on the density and reflection of the material on the mirror; therefore, students were in the wrong category.

\section{Measuring Skills}

In the indicator of the skill of measuring the density of the material and the reflection on the mirror, it shows that the students are in the wrong category with the percentage of $41.4 \%$ in the density material and $53.4 \%$ in the reflective material on the mirror, respectively. The indicators of measuring material density can be seen when students can measure the length of objects with a ruler 
measuring volume, can measure the mass of objects with a spring balance, can read the scale on a spring balance, and can determine the value of a spring balance scale to determine the mass of the object. As for the material on the reflection of the mirror on the indicators of measuring, it can be seen when students can measure the distance of objects to the mirror, can measure the length of the image to the mirror, can measure the range of the focal point. However, in this study, students were more likely to be passive in conducting experiments; therefore, students were categorized as not useful.

\section{Prediction Skills}

On the indicator of the skill to predict the density of the material and the reflection on the mirror, it shows that the students are in the first category with a percentage of $44.8 \%$ in the density material and $37.9 \%$ in the content on the mirror, respectively. The indicators of making predictions can be seen when students express the density of objects before measuring the mass of objects in the air, express the density of objects before measuring weight and immersed objects (using the Archimedes principle). The material reflecting on the mirror on the indicator making predictions can be seen when students can make predictions if objects are moved closer to or away from the mirror. In this study, it was observed that these students could predict the density well when the purpose was measured before and after the measurement was made. Simultaneously, for the material reflecting on the mirror, the students could predict well what would happen if the object was moved closer to or away from the mirror.

\section{E. Communication Skills}

On the indicators of communication skills, the density and reflection on the mirror showed that the students were in the first category with a percentage of $41.4 \%$ in the density material and $50.0 \%$ in the reflective material on the mirror, respectively. The indicators of communicating on density material can be seen when students discuss variables in the graph of the relationship of gravity to environmental density. Meanwhile, the reflective material on the mirror on the indicators of communication can be seen when students can discuss the measurement results with their group friends and present the experiment results. However, in this study, students were more likely to be passive when conducting experiments. It can occur because these students do not understand the density material concept and the reflection on the mirror being taught. Students tend to be passive not much in communication when asked to present the results the students tend to be silent and wait for an explanation from the researcher.

\section{F. Summing Skills}

In the skill indicator to conclude the density material and the reflection on the mirror, it shows that the students are in the wrong category with a percentage of $34.5 \%$ in the density material and $58.6 \%$ in the content on the mirror, respectively. In the conclusion indicator, the density material can be seen when students can express the magnitude of the force on the spring balance used for the density experiment of objects in the air, can show the data in the table to graph the variable relationship for the density experiment of objects in the air. As for the reflective material on the mirror on the concluding indicators, it can be seen when students can describe the properties of the image formed by a concave mirror, can express the relationship between object distance and image distance formed by a concave mirror, can show the value of the image distance formed by a concave mirror, can express the distance value of objects to the concave mirror, can reveal the distance value of the focal point, and relate the results of practice and theory. In this study, students could not represent the data in the table to graph the variable relationship for the density experiment of objects in the air. They could not relate the results of practice and theory.

\section{G. Variable Identification Skills}

On the indicator of the skill of identifying the material variable density and reflection on the mirror, it shows that the students are categorized as very bad and wrong with a percentage of $37.9 \%$ in density material, and $55.2 \%$ in the content reflected on the mirror, respectively. In the indicators of identifying the material variables, density and reflection on the mirror can be seen when students determine the independent variable, the dependent variable, and the constant variable. In this study, it was observed that students could not identify the variables used in the density experiment and the reflection on the mirror, even though the tools and materials they used were related to daily life.

\section{H. Skills to Arrange Data Tables}

In the skill indicator of compiling the data table material density and reflection on the mirror, it shows that students are in the wrong category with a percentage of $37.9 \%$ in density material and $56.9 \%$ in the content on the mirror reflection, respectively. In the skill indicators of compiling material data tables, the density can be seen when students can make three tables (density of objects, the relative density of fully submerged objects and relative frequency of partially immersed objects ) measurement data, can make appropriate labels (column headings) for each column, and can create experimental data. As for the material on the reflection of the mirror on the indicators compiling the data table can be seen when students can make a meal (object distance, image distance, focal point distance and the properties of the image formed) measurement data, can write measurement results in a table, can create a measurement repetition table, can create 
appropriate labels (column headings) for each column. In this study, it was seen that students were less able to make appropriate tables for each column and were less able to create data tables repeatedly.

\section{Graphics Skills}

In the skill indicator of making graphs of material density and reflection on the mirror, it shows that the students are in the wrong category with a percentage of $31.0 \%$ in the density material and $39.7 \%$ in the reflective material on the mirror, respectively. In the graphical skill indicator, density material can be seen when students can graph variable relationships from the relative density data of objects in the air, graph variable relationships from the comparable density data of objects immersed entirely in water, and graph variable relationships from object relative density data-partially submerged in water. While the material on the reflection of the mirror on the indicator makes a graphic that can be seen when students can graph the relationship between the variables from the data obtained (temperature to heat obtained when experimenting), and conclude the form of the graph that is made. In this study, most students could not graph correctly regarding the density graph and the reflection on the mirror.

\section{J. Skills to Acquire and Process Data}

On the indicators of skills in obtaining and processing data on the density and reflection of the material on the mirror, it shows that the students are in the wrong category with a percentage of $56.9 \%$ on the density material and $55.2 \%$ on the content on the mirror reflection, respectively. In the skill indicator in obtaining and processing data on the article, density can be seen when students can display data in the form of experimental results tables and can display data in the form of empirical data graphs. In contrast, the material on the reflection of the mirror on the indicator makes the chart visible when students can display data in the form of temporary data tables and can display data in the form of experimental data graphs. In this study, most students were unable to display data in the form of empirical data graphs.

\section{K. Skills to describe the relationship between variables}

In the skill indicator describing the relationship between the variable density material and the reflection on the mirror, it shows that the students are in the wrong category with a percentage of $56.9 \%$ in density material and $51.7 \%$ in the content on the mirror reflection, respectively. In the skill indicator describing the relationship between the material variables, density can be seen when students can criticize the magnitude of the experimental angle that has been set, can criticize the use of equations in determining the frequency of objects, and can make a parallel line for the relationship of the object's gravity to the environmental density. While the reflective material on the mirror on the skill indicator describing the relationship between variables can be seen when students can make a parallel line between object distance and image distance, discuss the relationship between object distance and image distance along with the focal point distance if there is a change in object distance, and discuss the relationship between object distance and image distance. The image distance and the focal point distance when there is a change in the object distance. In this study, students could not describe the relationship between variables so that students between groups could not discuss the relationship between variables in the graph.

\section{Skills to identify variables operationally.}

In the skill indicator to identify the variable operationally, the density and reflection material on the mirror showed that the students were in the wrong category with a percentage of $50.0 \%$ in density material and $53.4 \%$ in the reflective material, respectively. In the skill indicator to identify variables operationally, material density can be seen when students can take measurements to measure mass and volume in experiment 1 , can measure weight in air and bulk in water or pseudo in test 2 , take measurements to measure the mass of objects in the air, The mass of the immersed immersion, and the mass of the object and the immersion in water in experiment 3 , determine the density of the object using a caliper and a spring balance, use the Archimedes principle using water to measure the mass of the object, and select a block to measure its density. Meanwhile, the reflective material on the mirror on the indicator identifies the variable operationally. It can be seen when students can measure the distance of objects $(\mathrm{S})$, can measure the image distance ( $\left.\mathrm{S}^{\prime}\right)$, and measure the range of the focal point (f). In this study, some students were unable to measure and determine the density of objects using a caliper measuring instrument and a spring balance. Students could not measure object distance, image distance, and focus range correctly.

\section{Hypothesis Making Skills}

On the skill indicators to make hypotheses on the density of the material and the reflection on the mirror, it shows that the students are in perfect and excellent categories with a percentage of $37.9 \%$ in density material and $44.8 \%$ in the content reflected on the mirror, respectively. In the skill indicator, the material density hypothesis can be seen when students can adjust the experimental design with the theory and can decide that the innovative design is following the suggestion made. In contrast, the reflective material on the mirror on the indicators makes hypotheses that can be seen 
when students can make experimental hypotheses. In this study, most students can make hypotheses well.

\section{N. Experiment Analysis Skills}

On the indicators of experimental analysis skills, the density and reflection on the mirror showed that the students were in the wrong category with a percentage of $74.1 \%$ in the density material and $62.1 \%$ in the reflective material on the mirror, respectively. In the skill indicator to analyze the experimental material density can be seen when students can take the tools to be used in the density practicum after being observed, can make the material to be used in the density practicum after being watched, determine the actions to be used from the observation of the tools and materials used in design the object density experiment, specify the effect to be carried out from the representation of the tools and materials used in designing the object density experiment, determine the action to be carried out from the observation of the tools and materials used in creating the partial object relative density experiment. Simultaneously, the reflective material on the mirror on the experimental analysis indicator can be seen when students can design experiments according to the hypothesis. In this study, students could not decide that the innovative design as per the suggestion.

\section{O. Investigation Designing Skills}

On the indicators of designing experimental investigations of the density and reflection material on the mirror, it shows that the students are in the wrong category with a percentage of $62.1 \%$ in the density material and $34.5 \%$ of the reflected content on the mirror, respectively. In the skill indicators of designing the material density investigation, it can be seen when students can determine the tools and materials to be used in the density practicum using literature, can determine the main tools and materials to obtain the density of objects, can determine the main tools and materials to achieve the relative frequency of objects, can evaluate the tools and materials for getting the relative density of partially immersed objects. While the reflective material on the mirror on the indicators of designing an investigation can be seen when students can design experiments according to the hypothesis, it can decide that the experimental design is under the suggestion made. In this study, students could not determine the work steps by the objectives of the experiment; students tended to wait for orders from researchers in conducting investigations.

\section{P. Experimentation Skills}

The indicators of conducting experimental experiments on the density and reflection of the material on the mirror showed that the students were in the wrong category with a percentage of $60.3 \%$ in density material and $41.4 \%$ in the content on the mirror, respectively. In the indicator of the skill of conducting experiments, the material density can be seen when students prepare the tools appropriately according to their objectives, and the assembly of tools and materials that have been selected in the planning of the density experiment. While the reflective material on the mirror on the indicators of conducting experiments can be seen when students prepare tools and materials appropriately according to their objectives, how students place a concave mirror, candle, and screen on an optical bench, how students measure the distance of objects, how students measure image distance, how students measure the range of the focal point, can experiment according to the work order. In this study, students tend to be passive and do not know what to do, even though testing, the researcher has provided a practicum guide, but the students find it difficult to start doing experiments. The difficulty in preparing what tools will be used affects assembling tools and materials and conducting density and reflection experiments on mirrors.

The research results on each indicator of necessary and integrated science process skills show that students have low science process skills. Students' little science process skills are because students are rarely trained in discussion in learning subject matter or practicum [36]. This is consistent with research [37] to improve students' process skills through practical activities that lead to student activeness in discovering new things. The root of the problem is that learning is dominated by teachers so that students act as learning objects. The result is less experience for students to develop science process skills [38]. This is in line with the interviews that researchers have conducted.

The researcher also conducted interviews with two students to see the students' science process skills. The researcher provided five questions that contained aspects of science process skills on density material and reflection material on the chemerin. Following are the items and responses of the two students that the researcher has concluded as one

1. Do you like doing practicum activities? If you want, explain why

Student respondents: Don't like it. The reason is that I don't understand the concept of the material being taught, so indirectly, my friends and I are not enthusiastic about participating in the practicum activities that are being held.

2. When practicum takes place, if all rare $h$-step experiments do you do? Tell!

Student respondent: No, because to do the practical steps, I first have to understand the concept of the material to be carried out by the experiment. Because during the lesson, the teacher only explains in a broad outline of the content being studied without deepening how the concept is.

3. Do you like to observe, define variables, measure, and conclude the material practiced? Tell! 
Student respondent: No, during the observation activity, my friends and I did not take it seriously because we did not understand the concepts we received. This lack of understanding is because students are only taught existing ideas without any practical proof. Because educators focus on achieving the material being taught without paying attention to student understanding. For activities were defining variables, measuring, and concluding, we also have difficulty.

4. Do you understand the learning material better through practicum? Tell!

Student respondents: Yes, but during the practicum, my friends and I did not understand what we were doing. After the laboratory assistant evaluated at the end of the internship, we realized the material we were learning better.

\section{Do you want a practicum activity for every physics} lesson?

Student respondent: Yes, because we hope that in the future there will be more emphasis on understanding concepts through practicum activities

From the results of the interview, it was seen that, through practicum activities, it was observed that junior high school students' science process skills were in a low category. The results of the interviews conducted are closely related to the results of observations made by researchers. Because in general, they rarely carry out practical activities so that students do not explore science process skills and not all students like practicum activities so that their abilities are different. Science process skills and critical thinking skills are closely related, because students who do not have the skills of the scientific process, the student's thinking will not be critical.

The researcher also conducted interviews with two students to see the students' critical thinking skills. The researcher provides five questions that contain essential thinking skills in the density material and the material reflected in the chemerin. The following are the items and responses of the two students that the researcher has concluded as one

1. Besides getting content from the teacher, do you always look for additional physics material from books or other references? Tell!

Student respondents: No, because my friends and I tend to wait for the content that the teacher delivers without exploring more from various sources.

2. Do you think that the more difficult the problem is given, the more challenged you will be to find a solution? Tell!

Student respondent: No, because the questions are painful if I don't understand the concept of the material, the enthusiasm for doing or finding out is getting smaller. I will be challenged to work on the problems given when I understand the concept of the material being taught.
3. Are you actively working on the assignment given by the teacher? Tell

Student respondent: No, because I lack an understanding of concepts, and I can't do jobs individually.

4. Do you always answer questions asked by teachers? Tell!

Student response: Sometimes, because when I understand the question being asked, I will answer it with enthusiasm.

5. Do you often ask questions when you find it difficult to learn physics? Tell!

Student response: Sometimes, if I don't understand and the material I think is interesting to follow, I will be enthusiastic about receiving the lesson, and I will be happy to ask questions when I don't understand the material.

From the results of the interview above, it can be concluded that students have low critical thinking skills. It is in line with the research results that researchers have conducted using research instruments in the form of test questions that contain aspects of critical thinking skills. The results of the analysis of students 'critical thinking skills on the material because it is known that the students' critical thinking skills are classified as very low, this is because the highest percentage obtained by students is $36.2 \%$, which is in the deficient category. Material reflection of the mirror shows that the students' critical thinking skills are classified as not useful; this is said to be the highest percentage obtained by students who are in the low category with a percentage of $44.1 \%$. Students' low ability to think critically is due to, among other things, the learning that is applied in schools is still dominated by teachers so that they do not 'critical thinking skills and the students' low critical thinking skills are because students are getting with C4-C6 cognitive level. The learning method used is also capable of obeying critical thinking abilities, not all students can be taught the same method.

Teachers still dominate physics learning; learning tends essential skills of thinking develop thinking power so that students are weak in conveying their ideas, weak in analyzing, depending on others rather than being abilities of thought, not [9]. Science teaching in Indonesia on memorizing science concepts [40]. So the teacher must be able to create learning that trains students 'critical thinking skills. Training students' critical thinking skills that are done well will increase student interest in education and be confident in solving problems so that learning outcomes are maximized. So it is necessary to do better coaching to improve students' critical thinking skills [41]. Critical thinking is very important for students because of the ability to think students can improve learning outcomes of physics in school and be able to develop science process skills [42].

Furthermore, the effect of science process skills with critical thinking skills on the density and reflection on the mirror is in table 5. Based on the resulting significance 
value, it can be said that the influence of science process skills with critical thinking skills on the material density and reflection on the mirror is powerful. So that if the students 'science process skills are low, the students' critical thinking skills are also small, and if the students 'science process skills are high, their critical thinking skills are too high. It is evident in this study that students have low process skills and little critical thinking skills. Based on research conducted by [21], it appears that science process skills have a strong relationship with critical thinking. Students with low science process skills have moderate or low critical thinking skills. Critical thinking skills are required to understand the concept well [43].

\section{Conclusions}

Science process skills and critical thinking skills of Junior high School and Islamic Junior High School students are in a low category. Science process skills have a significant effect on students' critical thinking skills. If the students 'science process skills are low, the students' critical thinking skills are also little, and if the students 'science process skills are high, the students' critical thinking skills are too high. In this study, it can be seen that Junior high School and Islamic Junior High School students have low science process skills and critical thinking skills. The little science process skills of students are because students are rarely trained in discussion in learning subject matter or practicum and the students 'low critical thinking skills are because the learning applied in schools is still dominated by teachers so that students lack critical thinking skills and students' low critical thinking skills. Because students are not used to getting questions with a cognitive level of C4-C6. To improve science process skills and critical thinking skills needed to do the learning that is centered on students and familiarize students doing the learning level of the high and the need for understanding of concepts through practical activities.

\section{Acknowledgments}

Researchers would like to thank the headmaster of Adhyaksa 1 Junior High School and Jambi Al-Jauharen Islamic Junior High School, to the teachers. Of course, the researchers would like to thank the students who were willing to be the sample in this study. And the researchers acknowledge all the parties involved in this research.

\section{REFERENCES}

[1] A. Astalini, D. A. Kurniawan, and A. D. Putri, "Identifikasi Sikap Implikasi Sosial dari IPA, Ketertarikan Menambah Waktu Belajar IPA, dan Ketertarikan Berkarir Dibidang IPA
Siswa SMP Se-Kabupaten Muaro Jambi," J. Tarb. J. Ilm. Kependidikan, vol. 7, no. 2, pp. 93-108, 2018.

[2] M. Manan, "The Implementation of the Right to Education in Indonesia," Indones. Law Rev., vol. 5, no. 1, p. 51, 2015.

[3] E. Triyanto, S. Anitah, and N. Suryani, "Peran Kepemimpinan Kepala Sekolah dalam Pemanfaatan Media Pembelajaran sebagai Upaya Peningkatan Kualitas Proses Pembelajaran," J. Teknol. Pendidik., vol. 1, no. 2, pp. 226238, 2013.

[4] A. Astalini, D. A. Kurniawan, R. Perdana, and D. Kurniasari, "Identification of Student Attitudes toward Physics Learning at Batanghari District High School," Educ. Rev. USA, vol. 2, no. 9, pp. 475-484, 2018.

[5] D. Darmaji, D. A. Kurniawan, A. Astalini, and N. R. Nasih, "Persepsi Mahasiswa pada Penuntun Praktikum Fisika Dasar II Berbasis Mobile Learning," J. Pendidik. Teor. Penelitian, dan Pengemb., vol. 4, no. 4, pp. 516-523, 2019.

[6] T. djudin dan R. setiawan Eka Trisianawati, "PENGARUH MODEL PEMBELAJARAN KOOPERATIF TIPE JIGSAW TERHADAP HASIL BELAJAR SISWA PADA MATERI VEKTOR Kata kunci: Jigsaw, Hasil Belajar, Vektor I . PENDAHULUAN Fisika merupakan ilmu yang mempelajari benda - benda yang ada kejadian - kejadian alam serta in," J. Pendidik. Fis. dan Apl., vol. 06, no. 02, pp. 51-60, 2016.

[7] D. H. Young and R. A. Freedman, Fisika Universitas. Jakarta: Erlangga, 2002.

[8] R. Le Myers, The Basic of Physics. London: Greenwood Press, 2006.

[9] S. Wahyuni, I. Indrawati, S. Sudarti, and W. Suana, "Developing science process skills and problem-solving abilities based on outdoor learning in junior high school," $J$. Pendidik. IPA Indones., vol. 6, no. 1, pp. 165-169, 2017.

[10] A. Aydın, "International Journal of Education and Practice REPRESENTATION OF SCIENCE PROCESS SKILLS IN THE CHEMISTRY,” vol. 1, no. 5, pp. 51-63, 2013.

[11] S. Karamustafaoğlu, "Improving the Science Process Skills Ability of Science Student Teachers Using I Diagrams," Eurasian J. Phys. Chem. Educ, vol. 3, no. 1, pp. 26-38, 2011.

[12] A. Budiyono and H. Hartini, "Pengaruh Model Pembelajaran Inkuiri Terbimbing Terhadap Keterampilan Proses Sains Siswa SMA," Wacana Didakt., vol. 4, no. 2, pp. 141-149, 2016.

[13] A. M. Hutagalung, "Efek Model Pembelajaran Inquiry Training Berbasis Media Komputer Terhadap Keterampilan Proses Sains Dan Kemampuan Berpikir Kritis Siswa," J. Pendidik. Fis., vol. 2, no. 2, p. 9, 2013.

[14] Y. Yuliati, "PENINGKATAN KETERAMPILAN PROSES SAINS SISWA SEKOLAH DASAR MELALUI MODEL PEMBELAJARAN BERBASIS MASALAH,” vol. 2, no. 2 , 2016.

[15] D. Darmaji, D. A. Kurniawan, A. Suryani, and A. Lestari, “An Identification of Physics Pre-Service Teachers' Science Process Skills Through Science Process Skills-Based Practicum Guidebook,” J. Ilm. Pendidik. Fis. Al-Biruni, vol. 7, no. 2, p. 239, 2018. 
[16] N. Hırça, "The Influence of Hands on Physics Experiments on Scientific Process Skills According to Prospective Teachers' Experiences," Eur. J Phys. Educ., vol. 4, no. 1, pp. $1-9,2012$.

[17] D. Darmaji, D. A. Kurniawan, and A. Lestari, "Deskripsi keterampilan proses sains mahasiswa pendidikan fisika pada praktikum suhu dan kalor," J. Ris. dan Kaji. Pendidik. Fis., vol. 5 , no. 2 , p. $68,2018$.

[18] R. G. Raj and S. N. Devi, "SCIENCE PROCESS SKILLS AND ACHIEVEMENT IN SCIENCE AMONG HIGH," Sch. Res. J. Interdiscip. Stud., vol. 2, no. 15, pp. 2435-2443, 2014.

[19] V. M. Chabalengula, F. Mumba, and S. Mbewe, "How Pre-service Teachers 'Understand and Perform Science," Eurasia J. Math. Sci. Technol. Educ., vol. 8, no. 3, pp. 167176, 2012.

[20] G. Klein, "Critical thoughts about critical thinking," Theor. Issues Ergon. Sci., vol. 12, no. 3, pp. 210-224, 2011.

[21] A. J. Nugraha, H. Suyitno, and E. Susilaningsih, "Analisis Kemampuan Berpikir Kritis Ditinjau dari Keterampilan Proses Sains dan Motivasi Belajar melalui Model PBL," $J$. Prim. Educ., vol. 6, no. 1, pp. 35-43, 2017.

[22] B. Utami, S. Saputro, A. Ashadi, M. Masykuri, and S. Widoretno, "Critical thinking skills profile of high school students in learning chemistry," Int. J. Sci. Appl. Sci. Conf. Ser., vol. 1, no. 2, p. 124, 2017.

[23] H. Johan, "Pengaruh Sscs Problem Solving Untuk Meningkatkan Keterampilan Berpikir Kritis Mahasiswa Pada Pembelajaran Konsep Listrik Dinamis," J. Pendidik. Mat. dan IPA, vol. 4, no. 1, pp. 13-19, 2014.

[24] A. Shaw et al., "Thinking critically about critical thinking: validating the Russian HEIghten ${ }^{\circledR}$ critical thinking assessment," Stud. High. Educ., vol. 5079, 2019.

[25] R. Syafitri, R. Asyhar, and ) Asrial, "Pengaruh Model Inquiry Training dan Berpikir Kritis Terhadap Kemampuan Berpikir Ilmiah Mahasiswa pada Mata Kuliah Kimia Dasar The Effescts of Inquiry Training Model and Critical Thingking to the Students's Scientific Thingking Skills on the Subject of Che," vol. 5, no. 1, 2016.

[26] D. Ritdamaya and A. Suhandi, "Konstruksi Instrumen Tes Keterampilan Berpikir Kritis Terkait Materi Suhu dan Kalor," J. Penelit. Pengemb. Pendidik. Fis., vol. 02, no. 2, pp. 87-96, 2016.

[27] D. T. Tiruneh and M. De Cock, "Measuring Critical Thinking in Physics: Development and Validation of a Critical Thinking Test in Electricity and Magnetism," 2016.

[28] P. D. Sundari, Parno, and S. Kusairi, "KEMAMPUAN BERPIKIR KRITIS SISWA DALAMMODEL PEMBELAJARAN TERINTEGRASI Putri," $J$. KEPENDIDIKAN, vol. 2, no. 2, pp. 348-360, 2018.

[29] A. H. Aminudin, D. Rusdiana, A. Samsudin, L. Hasanah, and J. Maknun, "Measuring critical thinking skills of 11th grade students on temperature and heat," J. Phys. Conf. Ser., vol. 1280 , no. 5,2019 .

[30] Sugiyono, Statistika untuk penelitian. Bandung: Alfa Beta, 2016.

[31] J. W. Creswell, "Research Design: Pendekatan Kualitatif, Kuantitatif, dan Mixed,” Yogyakarta: Pustaka pelajar, 2013.

[32] M. Machmud, Tuntunan Penulisan Tugas Akhir Berdasarkan Prinsip Dasar Penelitian Ilmiah. Jakarta: Erlangga, 2005.

[33] E. K. Sinaga, Z. Matondang, and H. Sitompul, Statistika: Teori dan Aplikasi Pada Pendidikan. Jakarta: Yasasan Kita Menulis, 2009.

[34] A. Yadaeni, S. Kusairi, and parno, "Penguasaan Konsep dan Keterampilan Proses Sains Siswa Kelas XII pada Materi Fluida Statis," J. Pendidik. Teor. Penelitian, dan Pengemb., vol. 3, no. 3, pp. 357-364, 2018.

[35] A. H. Zeidan and M. R. Jayosi, "Science Process Skills and Attitudes toward Science among Palestinian Secondary School Students," World J. Educ., vol. 5, no. 1, pp. 13-24, 2015.

[36] S. Özgelen, "Students' science process skills within a cognitive domain framework," Eurasia J. Math. Sci. Technol. Educ., vol. 8, no. 4, pp. 283-292, 2012.

[37] Darmaji, D. A. Kurniawan, Astalini, A. Lumbantoruan, and S. C. Samosir, "Mobile learning in higher education for the industrial revolution 4.0: Perception and response of physics practicum," Int. J. Interact. Mob. Technol., vol. 13, no. 9, pp. 4-20, 2019.

[38] D. U. Ningsih, S. Santosa, and B. Sugiharto, "Penerapan Strategi Pembelajaran Think Talk Write Berbasis Kontekstual Untuk Meningkatkan Keterampilan Proses Sains Siswa Kelas X-8 SMA Negeri 1 Sukoharjo Tahun Pelajaran 2010/2011," Pendidik. Biol., vol. 3, no. 2, pp. 5564, 2011.

[39] A. Muhlisin, H. Susilo, M. Amin, and F. Rohman, "Improving critical thinking skills of college students through RMS model for learning basic concepts in science," Asia-Pacific Forum Sci. Learn. Teach., vol. 17, no. 1, 2016.

[40] B. A. Prayitno, D. Corebima, H. Susilo, S. Zubaidah, and M. Ramli, "Closing the science process skills gap between students with high and low level academic achievement," $J$. Balt. Sci. Educ., vol. 16, no. 2, pp. 266-277, 2017.

[41] G. Çavdar and S. Doe, "Learning through writing: Teaching critical thinking skills in writing assignments," PS - Polit. Sci. Polit., vol. 45, no. 2, pp. 298-306, 2012.

[42] S. Husein, L. Herayanti, and G. Gunawan, "Pengaruh Penggunaan Multimedia Interaktif Terhadap Penguasaan Konsep dan Keterampilan Berpikir Kritis Siswa pada Materi Suhu dan Kalor," J. Pendidik. Fis. dan Teknol., vol. 1, no. 3, p. 221, 2017.

[43] Puspita, Kurniawati, and Suwarma, "Analysis of Critical Thinking Skills on The Topic of Static Fluid Analysis of Critical Thinking Skills on The Topic of Static Fluid," Int. Conf. Math. Sci. Educ., 2017. 